\title{
Effect of Perceived Value on Customer Satisfaction, Loyalty and Service Quality of Selected Hospitals in Chhattisgarh
}

\author{
Pushkar Dubey, Satish Kumar Sahu
}

\begin{abstract}
Health care sector in India has grown fast in the past few decades. The primary reason for existence of health care sector is to provide care for its patients and to satisfy their needs. Providing excellence in service is an imperative determinant for the escalation and development of health care units. The present study seeks to identify the effect of customers perceived value on customer satisfaction, loyalty and service quality of selected hospitals in the state of Chhattisgarh. With the help of 400 inpatient and outpatient sample respondent's data were collected from ten hospitals covering four districts of Chhattisgarh. Purposive sampling technique was adopted for data collection with structured questionnaire. Structured equation modelling was performed for data analysis with the help of smart PLS v3 (trial). The study outcome revealed that the dimension customer perceived value is found to have positive effect on service quality, customer satisfaction and customer loyalty in health care sector of Chhattisgarh. Perceived value is also found to positively predict the dimension of service quality including assurance, tangibility, reliability, responsiveness and empathy.
\end{abstract}

Index Terms: Customer loyalty, Customer satisfaction, Hospital, Perceived Value, Service quality

\section{INTRODUCTION}

Hospitals are the health care institutions which provides treatment with specialised medical services. It is one of the sector that acquires a prominent place in the service industry. The hospital industry has been in cut throat competition in the market in past decade [1]. Health care sector in India has a high growth rate since it attracts demand from both international and domestic patients [2]. Service sector has potential to earn profitability and hence has been an area of interest for the investors. The value of the health care market of India is US\$65 billion. Presently health care sector is grooming and acts as a base for service sector. It is a sector of returns with strong national demand . The country spends $4 \%$ of its GDP on healthcare, with national health care expenditure of $25 \%$ [3]. Offered services are the amalgam of two parties which revolves around service providers and the consumers. Not all the services are tangible but a combination of both tangibles and intangibles component. With respect to health care it mostly constitutes of the intangible component [3]-[5]. Services offered by the health care are measured by the patients or the customers who avail them and on the basis of that they exhibit satisfaction. Customer/patient satisfaction is the degree to which customer feels contented with product and services offered by organisation which is an instrument for shaping customers repurchase intention and customer loyalty [6]. Service quality component for its enhancement can be related to strategic planning process and hence find a prominent place for the development in the health care sector [7],[8]. Literature suggests that service quality affects the behavior of consumer of services [9]. It can be stated in the form of benefits and costs. Mathematically it is the difference between the benefits (as per consumers perception) and the actual cost (which the consumers pay) from purchase of services [10]-[12]. Customer loyalty refers to patients' reassurance to revisit a hospital for obtaining further health-care services. Building loyalty is a long-term process [13]. Perceived value of the customers, services offered by firms and satisfaction and loyalty of customers tends to provide competitive advantage to the firm and contribute to the image of the organisation [14]. The service quality construct was given by Parsuraman, Zeithaml and Berry, 1984, 1988, 1994 followed the qualitative and quantitative research [15]-[17]. This measurement is widely accepted containing 22 items, also called as SERVIQUAL (service quality). The instrument measures service quality on five different dimensions i.e. tangibility, responsiveness, reliability, assurance and empathy. Tangibility is the components of physical facilities and equipment's. According to Zeithaml and Bitner, the customer experiences and their repurchase intention are affected by service quality, moreover they can help in formulation of suitable experiences [18]. Reliability can be defined in terms of promise made to the customers for delivering the service in a more efficient and accurate manner. In more simple term it is trustworthiness of information [19]. Responsiveness may be defined in terms of assistance provided to the customers for timely services [20]. Assurance is the belief and sureness with which the service provider inspires their customers. Empathy is the caring attitude, which seeks personal attention of the customer. Whereas knowledge and behaviour of employee with the ability to deliver trust and deal with users' request is the main idea of assurance [16] and is defined as caring and personalized attention that the firm provides to its product users [21].
Revised Manuscript Received on August 25, 2019.

Pushkar Dubey, Assistant Professor \& Head in Department of Management, Pandit Sundarlal Sharma (Open) University Chhattisgarh Bilaspur

Satish Kumar Sahu, Ph.D. scholar in the Department of Management from Pandit Sunderlal Sharma (Open) University Chhattisgarh, Bilaspur 


\section{Effect of Perceived Value on Customer Satisfaction, Loyalty and Service Quality of Selected Hospitals in Chhattisgarh}

Model modification in the SERVQUAL (service quality) to SERVPERF (service performance) was made by Cronin and Taylor, 1994 which contains 22 items [22]. SERVPERF approach is a better tool for measurement of service quality than SERVQUAL.

\section{REVIEW OF LITERATURE}

There are ample to studies, which describes the relationship between perceived value, service quality, customer satisfaction and customer loyalty.

\section{A. Perceived value in association between service quality and customer satisfaction}

There are ample of literature showing the relationship between perceived value, service quality and customer satisfaction. Perceived value is found to be a partial mediator in between service quality and customer satisfaction [23], Customer satisfaction grounded with degree of value and perceived value is a key antecedent of satisfaction [24]. Perceived value is found as a intervening and moderating factor between service quality and customer satisfaction in multiple service industry [25]-[27]. Many studies in literature, which agreeably underline that equal weight is put in each with the effect of service quality and satisfaction and loyalty of customers [28]-[34]. Positive relationship of customer value with quality and satisfaction in restaurant service industry was also found [16].

\section{B. Effect of Perceived value on Customer loyalty}

Customer loyalty the aftermath of customer perceived value and encourages organization performance [35]. It also develops competitive advantage among firms [36]. The overall loyalty that the customers receive can be stated in terms of consumer's expectation and actual receiving of value [37]. Customer loyalty concept is driven by the theory that the customers firstly forms the expectation regarding the value they wish to receive from a particular service and after receiving the service if their expectation match his actual service performed that they tend to receive satisfaction or else feel dissatisfaction. When customer perceived value go above the anticipations of the customers, they feel satisfied [38], [39] and the repetition over a period of time leads to the creation of customer loyalty. [40]. Findings shows that both satisfaction and loyalty are correlated with customer perceived value [41],[42]. Perceived value has positive impact on patient loyalty have been supported in transport services [43]-[46]. In service industries like airline travel and retail customer perceived value is treated as a key component of loyalty [47]. Customer perceived value is a noteworthy precursor of customer loyalty in different sectors [48]-[50]. It is also found to have significant positive effect in e-business [51]-[54]. Many researchers have underline that perceived value positively and directly correlated with customer loyalty in hotel and internet services [25], [55]-[58]. High-perceived value could ominously raise customer loyalty [48].

\section{Perceived value effect on Customer Satisfaction}

According to Kotler and Keller, 2012 satisfaction is "a person's feelings of pleasure or disappointment resulting from comparing perceived products' performance (or outcome) in relation to his or her expectations" [12]. Dissatisfaction are the outcome of difference that exists between expected performance and actual performance, incase the difference is null, the customers feel satisfied, incase it exceeds expectation the customers feel delighted [12]. Customer perceived value significantly influence patient satisfaction in hospitals [35], [60], [61]. It is a direct path, and meaningfully affects the customer satisfaction [23],[24], [62]-[64]. Most of the studies supported the positive relationship between perceived value and customer satisfaction in various sectors of industries of India and abroad [35], [51], [65]-[73].

\section{Effect of Perceived value on Service Quality}

Literature also shows that perceived value and service quality are closely related to each other. There are numerous studies which shows that service quality positively influences perceived value in multiple service industries [14],[66],[67],[72]-[82].

\section{RESEARCH METHODOLOGY}

The hypothetical model proposed in the study is shown in figure 1 , it shows the association between perceived value and others variables in the study. It is proposed that perceived value has direct effect on service quality, customer loyalty and customer satisfaction in hospitals of Chhattisgarh.

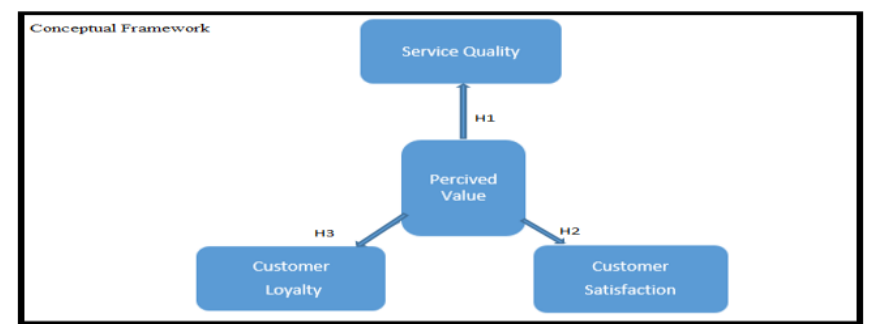

Fig 1: Conceptual Framework of Study

The factor service quality constructed of five constructs namely tangibility 4-items, reliability 5-items, responsiveness 4-items, assurance 4-items, and empathy 5-items, Factor perceived value constructed of 15 items, customer satisfaction with 5 items, and customer loyalty 7 items.

For sampling, the sample size of the study constitutes of 400 participants among four district of Chhattisgarh state. The inclusion criteria for the participants of the study were patients who went earlier to the hospitals for either general or surgical treatment and have spent at least one day in the hospital for treatments a patient. Respondents were patients who were not necessarily in patients at the hospital. Both inpatient and out-patients were included as sample respondent from both government and private hospitals. Ten different hospitals were chosen based on 100 plus beds, the instrument used for data collection consists of service quality scale consisting of 22 items develop by Cronin \& Taylor 1992. Self-structured scale on perceived value (15 items) customer loyalty ( 7 items), and customer satisfaction ( 5 items) were used in the study. All the items were measured using 7-point Likert scale ( $1=$ very dissatisfied; $7=$ Very satisfied). For the analysis of data, SPSS v25 (Licensed) and, SMART PLS v3 trial software were used. 
Hypotheses:

H1: Perceived value would be statistically significant in influencing customer satisfaction.

H2: Perceived value would be statistically significant in influencing customer loyalty.

H3: Perceived value would be statistically significant in influencing service quality.

H4: Perceived value would be statistically significant in influencing Assurance.

H5: Perceived value would be statistically significant in influencing Empathy.

H6: Perceived value would be statistically significant in influencing Reliability.

H7: Perceived value would be statistically significant in influencing Responsiveness.

H8: Perceived value would be statistically significant in influencing Tangibility.

The demographic profile of the respondent $(n=400)$ with their frequency, mean, standard deviation (SD) and confidence interval (CI) is shown in table 1 .

Table 1: Demographic profile of the respondents

\begin{tabular}{|c|c|c|c|c|c|}
\hline Variables & $\begin{array}{c}\text { Frequenc } \\
\mathbf{y}\end{array}$ & $\begin{array}{c}\text { Percen } \\
\mathbf{t}\end{array}$ & Mean & SD & CI [95\%] \\
\hline \multicolumn{6}{|l|}{ Age (Years) } \\
\hline Under 20 & 11 & 2.8 & 34.01 & $\begin{array}{c}0.78 \\
6\end{array}$ & $33.72-35.52$ \\
\hline $21-30$ & 152 & 38.0 & & & \\
\hline $31-40$ & 183 & 45.8 & & & \\
\hline $41-50$ & 45 & 11.3 & & & \\
\hline $50-60$ & 9 & 2.1 & & & \\
\hline \multicolumn{6}{|l|}{ Gender } \\
\hline Male & 244 & 61.0 & 1.39 & $\begin{array}{c}0.48 \\
8\end{array}$ & $1.34-1.44$ \\
\hline Female & 156 & 39.0 & & & \\
\hline \multicolumn{6}{|l|}{ Education } \\
\hline High School & 29 & 7.2 & 3.4 & $\begin{array}{c}1.06 \\
7\end{array}$ & $3.30-3.51$ \\
\hline $10+2$ & 48 & 12.0 & & & \\
\hline Graduate & 100 & 25.0 & & & \\
\hline Postgraduate & 179 & 44.8 & & & \\
\hline Others & 44 & 11.0 & & & \\
\hline \multicolumn{6}{|l|}{ Profession } \\
\hline $\begin{array}{l}\text { Govt. } \\
\text { Service }\end{array}$ & 146 & 36.5 & & & $2.19-2.46$ \\
\hline $\begin{array}{l}\text { Private } \\
\text { Service }\end{array}$ & 120 & 30.0 & & & \\
\hline Business & 50 & 12.5 & & & \\
\hline Cultivation & 26 & 6.5 & & & \\
\hline Others & 58 & 14.5 & & & \\
\hline $\begin{array}{l}\text { Monthly } \\
\text { Income }\end{array}$ & & & & & \\
\hline
\end{tabular}

\begin{tabular}{|c|c|c|c|c|c|}
\hline $\begin{array}{l}\text { Less than } \\
15000\end{array}$ & 88 & 22.0 & $\begin{array}{c}2604 \\
5\end{array}$ & $\begin{array}{c}1.39 \\
8\end{array}$ & $\begin{array}{c}25214-2800 \\
1\end{array}$ \\
\hline $\begin{array}{l}\text { Rs } \\
15001-2500 \\
0\end{array}$ & 87 & 21.6 & & & \\
\hline $\begin{array}{l}\text { Rs } \\
25001-3500 \\
0\end{array}$ & 102 & 25.6 & & & \\
\hline $\begin{array}{l}\text { Above Rs } \\
35000\end{array}$ & 123 & 30.8 & & & \\
\hline $\begin{array}{l}\text { Type of } \\
\text { Hospital } \\
\text { Visited }\end{array}$ & & & & & \\
\hline Government & 200 & 50.0 & 1.5 & $\begin{array}{c}0.50 \\
1\end{array}$ & $1.45-1.55$ \\
\hline Private & 200 & 50.0 & & & \\
\hline
\end{tabular}

Source: own Analysis from primary data source

\section{RESULTS AND FINDING}

All data after coding were entered into the statistical software were both measurement and structural models were evaluated.

\section{A. Evaluation of measurement models}

The model specified in the conceptual framework has four constructs with reflective measurement models, where estimates between their latent and manifest variables were examined. The outer loadings of all items used in this study are accepted. Table 2 reveals that customer loyalty (Cronbach's $\alpha=0.953, \mathrm{CR}=0.954$ and $\mathrm{AVE}=0.747$ ), similarly customer satisfaction (Cronbach's $\alpha=0.919, \mathrm{CR}=$ 0.920 and AVE $=0.698$ ), perceived value (Cronbach's $\alpha=$ $0.971, \mathrm{CR}=0.971$ and $\mathrm{AVE}=0.688$ ), assurance (Cronbach's $\alpha=0.851, \quad \mathrm{CR}=0.896$ and $\mathrm{AVE}=0.684)$, empathy (Cronbach's $\alpha=0.891, \mathrm{CR}=0.899$ and $\mathrm{AVE}=0.628$ ), Reliability (Cronbach's $\alpha=0.909, \mathrm{CR}=0.912$ and $\mathrm{AVE}=$ 0.675), responsiveness (Cronbach's $\alpha=0.927, \mathrm{CR}=0.927$ and AVE= 0.762) and tangibility (Cronbach's $\alpha=0.865, \mathrm{CR}=$ 0.866 and $\mathrm{AVE}=0.618$ ). The reliability measurement of construct is shown in table 2 .

The reliability of Cronbach's $\alpha>0.70$ the constructs found to be acceptance [83], [84]. Since, CR $>0.70$ is considered fair [85]. The AVE > 0.50 confirms the convergent validity of the construct [87].

Table: 2 Reliability measurement of the Constructs

\begin{tabular}{|c|c|c|c|}
\hline Construct & Alpha & CR & AVE \\
\hline Customer Loyalty & 0.953 & 0.954 & 0.747 \\
\hline Customer Satisfaction & 0.919 & 0.920 & 0.698 \\
\hline Perceived Value & 0.971 & 0.971 & 0.688 \\
\hline Assurance & 0.851 & 0.896 & 0.684 \\
\hline Empathy & 0.891 & 0.899 & 0.628 \\
\hline Reliability & 0.909 & 0.912 & 0.675 \\
\hline Responsiveness & 0.927 & 0.927 & 0.762 \\
\hline Tangibility & 0.865 & 0.866 & 0.618 \\
\hline
\end{tabular}




\section{Effect of Perceived Value on Customer Satisfaction, Loyalty and Service Quality of Selected Hospitals in Chhattisgarh}

\section{B. Discriminant Validity}

Discriminant validity checks whether two constructs in the study have statistical difference between each other. In other words it is used to find out the overlapping of two said constructs [83],[88],[89]. Table 3 demonstrates discriminant validity measurement of construct.

Table: 3 Discriminant Validity measurement of Construct

\begin{tabular}{|l|c|c|c|c|c|c|c|c|c|}
\hline & Assurance & $\begin{array}{c}\text { Customer } \\
\text { Loyalty }\end{array}$ & $\begin{array}{c}\text { Customer } \\
\text { Satisfaction }\end{array}$ & Empathy & $\begin{array}{c}\text { Perceived } \\
\text { Value }\end{array}$ & Reliability & Responsiveness & $\begin{array}{c}\text { Service } \\
\text { Quality }\end{array}$ & Tangibility \\
\hline Assurance & 0.995 & & & & & & & & \\
\hline $\begin{array}{l}\text { Customer } \\
\text { Loyalty }\end{array}$ & 0.876 & 0.946 & & & & & & & \\
\hline $\begin{array}{l}\text { Customer } \\
\text { Satisfaction }\end{array}$ & 0.842 & 0.943 & 0.928 & & & & & & \\
\hline Empathy & 0.944 & 0.862 & 0.775 & 0.997 & & & & & \\
\hline $\begin{array}{l}\text { Perceived } \\
\text { Value }\end{array}$ & 0.827 & 0.883 & 0.843 & 0.959 & 0.975 & & & & \\
\hline Reliability & 0.823 & 0.864 & 0.852 & 0.957 & 0.843 & 0.975 & & & \\
\hline Responsiveness & 0.977 & 0.887 & 0.835 & 0.812 & 0.957 & 0.921 & 0.931 & & \\
\hline $\begin{array}{l}\text { Serrice } \\
\text { Quality }\end{array}$ & 0.905 & 0.912 & 0.867 & 0.793 & 0.830 & 0.881 & 0.881 & 0.982 & \\
\hline Tangibility & 0.908 & 0.913 & 0.870 & 0.810 & 0.875 & 0.872 & 0.873 & 0.807 & 0.786 \\
\hline
\end{tabular}

The assessment of reliability and discriminant validity of the constructs shows that measurement model is fairly reliable and valid.

\section{Evaluation of the structural model}

The structural equation model was evaluated on basis of inspecting criteria that are determined by the model. This involves evaluation of path coefficient, direct effect, $t$ and $p$ value measures.

The validated data were analyzed with Smart PLS (trial) to construct variance based structural equation model for analysis. The procedure used was partial least square (PLS) path modelling [86],[87],[90]. Obtained coefficients, direct effects, etc. are depicted in table 4 and figure 2:

As demonstrated in table 4 all the path coefficients in the model have significant value indicating association between respective variables.

Based on the result in figure 2 and table 4; perceived value was found to be positively associated with customer satisfaction $\left(R^{2}=0.710, \beta=0.843, t=40.49, p<0.01\right)$ and explained $71 \%$ direct effect on the criterion variable customer loyalty. Perceived value also played a significant positive role and explained $78.0 \%$ direct effect on customer loyalty $\left(\mathrm{R}^{2}=\right.$ $0.780, \beta=0.883, t=59.960, p<0.01)$. Similarly, perceived value played a significant positive role and explained $95.1 \%$ direct effect on service quality $\left(\mathrm{R}^{2}=0.951, \beta=0.975, \mathrm{t}=\right.$ 294.066, $\mathrm{p}<0.01)$. Furthermore, service quality dimension assurance and perceived value are positively associated with each other $\left(\mathrm{R}^{2}=0.989, \beta=0.995, \mathrm{t}=152.337, \mathrm{p}<0.01\right)$, and explained $98 \%$ variances. Perceived value also played a significant positive role and explained $78 \%$ direct effect on tangibility $\left(\mathrm{R}^{2}=0.831, \beta=0.912, \mathrm{t}=74.486, \mathrm{p}<0.01\right)$. Perceived value also played a significant positive role and explained $94.6 \%$ direct effect on reliability. $\left(R^{2}=0.946, \beta=\right.$ $0.973, \mathrm{t}=129.610, \mathrm{p}<0.01)$. Perceived value also played a significant positive role and explained $91.6 \%$ direct effect on responsiveness $\left(R^{2}=0.916, \beta=0.975, t=155.661, p<0.01\right)$. Similarly, perceived value played a significant positive role and explained $92 \%$ direct effect on empathy $\left(R^{2}=0.920, \beta=\right.$ $0.959, \mathrm{t}=138.044, \mathrm{p}<0.01)$ Multicollinearity is not desirable. The value of variance inflation factor (VIF) was found 1.00 [68].

Table 4: Direct effect, Path coefficients (Total effect), T value and $P$ value

\begin{tabular}{|l|c|c|c|c|}
\hline \multicolumn{1}{|c|}{ Variables } & $\begin{array}{c}\text { Direct effect } \\
\text { (R Square) }\end{array}$ & $\begin{array}{c}\text { Path } \\
\text { coefficient } \\
(\boldsymbol{\beta})\end{array}$ & T Value & P Value \\
\hline $\begin{array}{l}\text { Perceived } \\
\text { Value-> } \\
\text { Customer } \\
\text { Satisfaction }\end{array}$ & 0.710 & $0.843^{* *}$ & 40.496 & 0.000 \\
\hline $\begin{array}{l}\text { Perceived } \\
\text { Value-> } \\
\text { Customer } \\
\text { Loyalty }\end{array}$ & 0.780 & $0.883^{* *}$ & 59.960 & 0.000 \\
\hline $\begin{array}{l}\text { Perceived } \\
\text { Value-> Service } \\
\text { Quality }\end{array}$ & 0.951 & $0.975^{* *}$ & 294.066 & 0.000 \\
\hline $\begin{array}{l}\text { Perceived Value } \\
\text { - Assurance }\end{array}$ & 0.989 & $0.995^{* *}$ & 152.377 & 0.000 \\
\hline $\begin{array}{l}\text { Perceived } \\
\text { Value-> } \\
\text { Tangibility }\end{array}$ & 0.831 & $0.912^{* *}$ & 74.486 & 0.000 \\
\hline $\begin{array}{l}\text { Perceived Value } \\
\text { - Reliability }\end{array}$ & 0.946 & $0.973^{* *}$ & 129.610 & 0.000 \\
\hline $\begin{array}{l}\text { Perceived Value } \\
\text { - } \\
\text { Responsiveness }\end{array}$ & 0.916 & $0.957^{* *}$ & 155.661 & 0.000 \\
\hline $\begin{array}{l}\text { Perceived Value } \\
->\text { Empathy }\end{array}$ & 0.920 & $0.959^{* *}$ & 138.044 & 0.000 \\
\hline p < 0.05*,p < 0.01** & & & \\
\hline
\end{tabular}

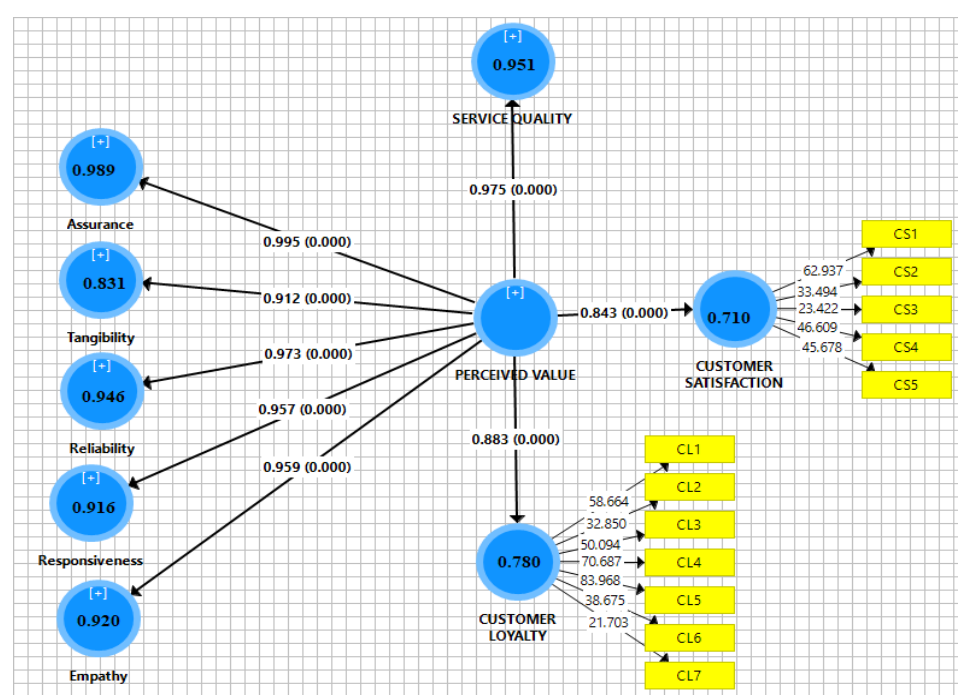

Figure 2: Structural equation model of all the variables

\section{CONCLUSION AND DISCUSSION}

The purpose of the study to predict the effect of service quality on perceived value, customer satisfaction and customer loyalty in hospitals of Chhattisgarh. The result of this study confirms the existence of a positive relationship between service quality on perceived value, customer satisfaction and customer loyalty. The study supports the first hypothesis of the study and finds that perceived value positively and statistical predicts customer satisfaction, which means that the customer expectation in relation to value they receive are well with in their satisfaction. 
This finding is similar to that of outcomes of the past literatures [25],[44]-[46],[48]-[50],[55]-[57].The findings also support the second hypothesis and reveals that perceived value positive and significant influence customer loyalty, which indicates that customer expectation regarding hospital services builds on their loyalty. This outcome also consistent that of the work of preceding studies [35],[51],[65],[66],[70]-[72]. The finding also supported the third hypothesis and confirms that customer perceived value has positively and significant influence on service quality dimension, which means that customer perception of values is regarded with the formation of service quality measures on hospital of the state. Also perceived value is found significant and positive relation with components of the service quality constructs i.e. assurance, empathy, reliability, responsiveness and tangibility. This outcome is also supported with studies done is the past [66],[67],[72],[73],[79],[80],[82].

The outcome heavily draws managerial implication on the study. It suggests that on increase in the perceived value of the customer would result in increase in their satisfaction level and thereby generate high customer loyalty. On the other hand, perceived value also result in higher domain of service quality i.e. increase in assurance, empathy, reliability responsiveness and tangibility.

\section{REFERENCES}

1. Raju, P. S., \& Lonial, S. C. (2002). The impact of service quality and marketing on financial performance in the hospital industry: an empirical examination. Journal of Retailing and Consumer Services, 9(6), pp.335-348.

2. Burns, R.L., 2014. India's Healthcare Industry - Innovation in Delivery, Financing and Manufacturing. Cambridge University Press, New Delhi.

3. Regan W.J. (1963). The Service Revolution, Journal of Marketing, 47, pp.57 - 62 .

4. Rathmell, J. M. (1966). What is meant by services?. Journal of marketing, 30(4), pp.32-36.

5. Shostack, G. L. (1977). Breaking free from product marketing. Journal of marketing, 41(2), pp.73-80.

6. Murti, M., Krajden, M., Petric, M., Hiebert, J., Hemming, F., Hefford, B. \& Van Buynder, P. (2013). Case of vaccine-associated measles five weeks post-immunisation, British Columbia, Canada. Eurosurveillance, 18(49), pp.206-49.

7. Donabedian, A. (1980). Exploratings in quality assessment and monitoring definition of quality and approaches to its assessment. Ann Arbor: Health Administration Press, pp.8-11.

8. Williams, S. J., \& Calnan, M. (1991). Key determinants of consumer satisfaction with general practice. Family practice, 8(3), pp.237-242.

9. Andaleeb, S. S. (2001). Service quality perceptions and patient satisfaction: a study of hospitals in a developing country. Social science \& medicine, 52(9), pp.1359-1370.

10. Heskett, J. L., Jones, T. O., Loveman, G. W., Sasser, W. E., \& Schlesinger, L. A. (1994). Putting the service-profit chain to work. Harvard business review, 72(2), pp.164-174.

11. Christopher, P., \& Payne, A. Ballantyne,(2008). The effectivences of relationship marketing strategies. USA, 25

12. Kotler, P., \& Keller, K. L. (2012). Marketing management: Global edition. Harlow: Pearson, 56.

13. Zeithaml, V. A., Bitner, M. J., \& Gremler, D. D. (2009). Services Marketing: Integrating. Customer Focus Across the Firm.

14. Bloemer, J., \& Odekerken-Schroder, G. (2002). Store satisfaction and store loyalty explained by customer-and store-related factors. Journal of Consumer Satisfaction Dissatisfaction and Complaining Behavior, 15(1), pp.68-80

15. Parasuraman, A., Zeithaml, V. A., \& Berry, L. L. (1985). A conceptual model of service quality and its implications for future research. Journal of marketing, 49(4), pp.41-50.

16. Parasuraman, A., Zeithaml, V. A., \& Berry, L. L. (1988). Servqual: A multiple-item scale for measuring consumer perc. Journal of retailing, 64(1), pp.12-40.
17. Parasuraman, A., Zeithaml, V. A., \& Berry, L. L. (1994). Reassessment of expectations as a comparison standard in measuring service quality: implications for further research. Journal of marketing, 58(1), 111-124.

18. Kincaid, C., Baloglu, S., Mao, Z., \& Busser, J. (2010). What really brings them back? The impact of tangible quality on affect and intention for casual dining restaurant patrons. International Journal of Contemporary Hospitality Management, 22(2), pp.209-220.

19. Karatepe, O. M., Yavas, U., \& Babakus, E. (2005). Measuring service quality of banks: scale development and validation. Journal of Retailing and Consumer Services, 12(5), pp.373-383

20. Abdullah, F., Suhaimi, R., Saban, G., \& Hamali, J. (2011). Bank service quality (BSQ) index: an indicator of service performance. International Journal of Quality \& Reliability Management, 28(5), pp.542-555.

21. Wang, C. L. (2007). Guanxi vs. relationship marketing: Exploring underlying differences. Industrial Marketing Management, 36(1), pp.81-86.

22. Cronin Jr, J. J., \& Taylor, S. A. (1994). SERVPERF versus SERVQUAL: reconciling performance-based and perceptions-minus-expectations measurement of service quality. Journal of marketing, 58(1), pp.125-131.

23. Hapsari, R., Clemes, M., \& Dean, D. (2016). The mediating role of perceived value on the relationship between service quality and customer satisfaction: Evidence from indonesian airline passengers. Procedia Economics and Finance, 35, pp.388-395.

24. McDougall, G.H.G., \& Levesque, T. (2000). Customer satisfaction with services: putting perceived value into the equation. Journal of Services Marketing, 14(5), pp.392-410.

25. Oh, H. (1999). Service quality, customer satisfaction, and customer value: a holistic perspective, International Journal of Hospitality Management, 18(1), pp.67-82.

26. Caruana, A., Money, A. H., \& Berthon, P. R. (2000). Service quality and satisfaction-the moderating role of value. European Journal of marketing, 34(11/12), pp.1338-1353.

27. Ryu, K., \& Han, H. (2010). Influence of the quality of food, service, and physical environment on customer satisfaction and behavioral intention in quick-casual restaurants: Moderating role of perceived price. Journal of Hospitality \& Tourism Research, 34(3), pp.310-329

28. Sternthal, B., Tybout, A. M., \& Calder, B. J. (1987). Confirmatory versus comparative approaches to judging theory tests. Journal of Consumer Research, 14(1), pp.114-125.

29. Iacobucci, D., Ostrom, A., \& Grayson, K. (1995). Distinguishing service quality and customer satisfaction: the voice of the consumer. Journal of consumer psychology, 4(3), pp.277-303.

30. Hennig Thurau, T., \& Klee, A. (1997). The impact of customer satisfaction and relationship quality on customer retention: A critical reassessment and model development. Psychology \& marketing, 14(8), pp.737-764.

31. Lynn, M. R., \& McMillen, B. J. ( 1999). Do nurses know what patients think is important in nursing care?. Journal of nursing care quality, 13(5), pp.65-74.

32. Duffy, J. A., Duffy, M., \& Kilbourne, W. E. (2001). A comparative study of resident, family, and administrator expectations for service quality in nursing homes. Health Care Management Review, 26(3), pp.75-85.

33. Chou, S. M., Chen, T. F., Woodard, B., \& Yen, M. F. (2005). Using SERVQUAL to evaluate quality disconfirmation of nursing service in Taiwan. The journal of nursing research: JNR, 13(2), pp.75-84.

34. Bojanic, D. C. (1996). Consumer perceptions of price, value and satisfaction in the hotel industry: An exploratory study. Journal of Hospitality \& Leisure Marketing, 4(1), pp.5-22.

35. Lam, S.Y., Shankar, V., Erramilli, M.K. and Murthy, B. (2004) Customer value, satisfaction, loyalty, and switching costs: an illustration from a business-to-business service context, Journal of the Academy of Marketing Science, 32 (3), pp.293-311.

36. Bloemer, R., \& De Ruyter, L. Peeters (1998). Investigating Drivers of Bank Loyalty: the Complex Relationship between Image, Service Quality and Satisfaction. International Journal of Bank Marketing, 16(7), pp.276-28

37. Gounaris, S. P., Tzempelikos, N. A., \& Chatzipanagiotou, K. (2007). The relationships of customer-perceived value, satisfaction, loyalty and behavioral intentions. Journal of Relationship Marketing, 6(1), 63-87. 


\section{Effect of Perceived Value on Customer Satisfaction, Loyalty and Service Quality of Selected Hospitals in}

Chhattisgarh

38. Oliver, R. L. (1981). Measurement and evaluation of satisfaction processes in retail settings. Journal of retailing.

39. Anderson, E. W., Fornell, C., \& Lehmann, D. R. (1994). Customer satisfaction, market share, and profitability: Findings from Sweden. Journal of marketing, 58(3), pp.53-66.

40. Ravald, A., \& Grönroos, C. (1996). The value concept and relationship marketing. European journal of marketing, 30(2), pp.19-30.

41. Wang, Y., Po Lo, H., Chi, R., \& Yang, Y. (2004). An integrated framework for customer value and customer-relationship-management performance: a customer-based perspective from China. Managing Service Quality: An International Journal, 14(2/3), pp.169-182.

42. Gallarza, M. G., \& Saura, I. G. (2006). Value dimensions, perceived value, satisfaction and loyalty: an investigation of university students' travel behaviour. Tourism management, 27(3), pp.437-452.

43. Jen, W., \& Hu, K. C. (2003). Application of perceived value model to identify factors affecting passengers' repurchase intentions on city bus: A case of the Taipei metropolitan area. Transportation, 30(3), pp.307-327.

44. Choi, K. S., Cho, W. H., Lee, S., Lee, H., \& Kim, C. (2004). The relationships among quality, value, satisfaction and behavioral intention in health care provider choice: A South Korean study. Journal of Business Research, 57(8), pp.913-921.

45. Basir, M., Modding, B., Kamase, J. and Hasan, S., 2015. Effect of Service Quality, Orientation Services, and Pricing on Loyalty and Customer Satisfaction on Marine Transportation Services. International Journal of Humanities and Social Science Invention, 4(6), pp.1-6.

46. Lai, W. T., \& Chen, C. F. (2011). Behavioral intentions of public transit passengers - The roles of service quality, perceived value, satisfaction and involvement. Transport policy, 18(2), pp.318-325.

47. Sirdeshmukh D, Singh J, Sabol B. 2002. Consumer trust, value, and loyalty in relational exchanges. Journal of Marketing, 66(1), pp.15-37.

48. Oliver, R. L., \& DeSarbo, W. S. (1988). Response determinants in satisfaction judgments. Journal of consumer research, 14(4), pp.495-507.

49. Parasuraman, A., \& Grewal, D. (2000). The impact of technology on the quality-value-loyalty chain: a research agenda. Journal of the academy of marketing science, 28(1), pp.168-174.

50. Olsen, L. L., \& Johnson, M. D. (2003). Service equity, satisfaction, and loyalty: from transaction-specific to cumulative evaluations. Journal of Service Research, 5(3), pp.184-195.

51. Yang, Z., \& Peterson, R.T. (2004). Customer perceived value, satisfaction, and loyalty: The role of switching costs. Psycology and Marketing, 21(10), pp.799-822.

52. Marimon, F., Vidgen, R., Barnes, S., and Cristóbal, E. (2009). Purchasing behaviour in an online Supermarket: The applicability of E-S-QUAL, International Journal of Market Research, 52 (1) pp.111-129.

53. Fuentes-Blasco, M., Saura, I., Berenguer-Contr1, G., and Moliner-Vela'zquez, B. (2010). Measuring the antecedents of e-loyalty and the effect of switching costs on website, The Service Industries Journal, 30(11), pp.1837-1852.

54. Pearson, A., Tadisina, S., and Griffin, C. (2012), The role of e-service quality and information quality in creating perceived value antecedents to web site loyalty, Information Systems Management 29(3), pp.201-215

55. Poon, W.C. and Low, K.L.T. (2005). Are travellers satisfied with Malaysian hotels?, International Journal of Contemporary Hospitality Management, 17(3), pp.217-27.

56. Gill, D., Byslma, B. and Ouschan, R. (2007). Customer perceived value in a cellar door visit: the impact on behavioural intentions, International Journal of Wine Business Research, 19(4), pp.257-75

57. Nasution, H.N. and Mavondo, F.T. (2008). Customer value in the hotel industry: what managers believe they deliver and what customer experience, International Journal of Hospitality Management, 27(2), pp.204-13

58. Kim, K.J., Jeong, I.J., Park, J.C., Park, Y.J., Kim, C.G. and Kim, T.H. (2008). The impact of network service performance on customer satisfaction and loyalty: high-speed internet service case in Korea, Expert Systems with Applications, 32(3), pp.822-31.

59. Tam, J. L. (2004). Customer satisfaction, service quality and perceived value: an integrative model. Journal of marketing management, 20(7-8), pp.897-917.

60. Hu, H., Kandampully, J. and Juwaheer, T.D. (2009). Relationships and impacts of service quality, perceived value, customer satisfaction, and image: an empirical study, The Service Industries Journal, 29(2), pp.111-25.

61. Lee, W. I., Chen, C. W., Chen, T. H., \& Chen, C. Y. (2010). The relationship between consumer orientation, service value, medical care service quality and patient satisfaction: The case of a medical center in Southern Taiwan. African Journal of Business Management, 4(4), pp.448-458.

62. Johnson, M. D., Gustafsson, A., Andreassen, T. W., Lervik, L., \& Cha, J. (2001). The evolution and future of national customer satisfaction index models. Journal of economic Psychology, 22(2), pp.217-245.

63. Walter, A., Mueller, T. A., \& Helfert, G. (2000). The impact of satisfaction, trust, and relationship value on commitment: Theoretical considerations and empirical results. In IMP Conference Proceedings (7), pp.07-09.

64. Kuo, Y. F., Wu, C. M., \& Deng, W. J. (2009). The relationships among service quality, perceived value, customer satisfaction, and post-purchase intention in mobile value-added services. Computers in human behavior, 25(4), pp.887-896.

65. Anderson, E. W., \& Mittal, V. (2000). Strengthening the satisfaction-profit chain. Journal of Service research, 3(2), pp.107-120.

66. Cronin, J.J. Jr, Brady, M.K. and Hult, G.T.M. (2000), Assessing the effects of quality, value, and customer satisfaction on consumer behavioral intentions in service environments, Journal of Retailing, 76(2), pp.193-218

67. Hellier, P.K., Geursen, G.M., Carr, R.A., Rickard, J.A. (2003). Customer repurchase intention, a general structural equation model, European Journal of Marketing, 37 (11/12), pp.1762-800.

68. O'brien, R. M. (2007). A caution regarding rules of thumb for variance inflation quantity, 41(5), pp.673-690.

69. Lai, F., Griffin, M. and Babin, B.J. (2009). How quality, value, image, and satisfaction create loyalty at a Chinese telecom, Journal of Business Research, 62 (10), pp.980-986

70. Fandos Roig, J. C., García, J. S., \& Moliner Tena, M. Á. (2009) Perceived value and customer loyalty in financial services. The Service Industries Journal, 29(6), pp.775-789.

71. Hume M; Mort G. S., (2010). The consequence of appraisal emotion, service quality, perceived value and customer satisfaction on repurchase intent in the performing arts, Journal of Services Marketing, 24, 170-182.

72. Chang Hsin Hsin, Wang Hsin-Wei, (2011). The moderating effect of customer perceived value on online shopping behaviour, Online Information Review, 35(3), pp.333 - 359.

73. Edward Manoj, Sahadev Sunil, (2011). Role of switching costs in the service quality, perceived value, customer satisfaction and customer retention linkage, Asia Pacific Journal of Marketing and Logistics 23(3), pp.327 - 345.

74. Cronin, J. J., Brady, M. K., Brand, R. R., Hightower, R., \& Shemwell, D. (1997). A crosssectional test of the effect and conceptualization of service value. The Journal of Service Marketing, 11(6), pp.375-391.

75. Sweeney, J.C., Soutar, G.N., \& Johnson, L.W. (1999). The role of perceived risk in the quality-value relationship: a study in a retail environment. Journal of Retailing, 75(1), pp.77-105.

76. Teas, R.K., \& Agarwal, S. (2000). The effect of extrinsic product cues on consumer's perceptions of quality, sacrifice and value. Journal of the Academy of Marketing Science, 28(2), 2 pp.78-290

77. Brady, M. K., Robertson, C. J., \& Cronin, J. J. (2001). Managing behavioral intentions indiverse cultural environments: An investigation of service quality, service value, and satisfaction for American and Ecuadorian fast-food customers. Journal of International Management, 7(2), pp.129-149.

78. Chumpitaz, R., \& Paparoidamis, N.G. (2004). Service quality and marketing performance in business-to-business markets: Exploring the mediating role of client satisfaction. Managing Service Quality: An International Journal, 14(2/3), pp.235-248.

79. Snoj, B., Korda, A.P., \& Mumel, D. (2004). The relationships among perceived quality, perceived risk and perceived product value. Journal of Product and Brand Management, 13(3), pp.156-167.

80. Bauer, H. H., Falk, T., \& Hammerschmidt, M. (2006). eTransQual: A transaction process-based approach for capturing service quality in online shopping. Journal of Business Research, 59(7), pp.866-875. 
81. Turel, O., \& Serenko, A. (2006). Satisfaction with mobile services in Canada: An empirical investigation. Telecommunications Policy, 30(5/6), pp.314-331.

82. Dobre, C., Dragomir, A.C., \& Milovan-Ciuta, A.-M. ( 2013). A marketing perspective on the influences of waiting time and the service scape on perceived value. Management \& Marketing, 8(4), pp.683-698.

83. Fornell, C., \& Larcker, D. F. (1981). Evaluating structural equation models with unobservable variables and measurement error. Journal of Marketing Research, 18(1), pp.39-50.

84. Bryman, A. (2008). Social research methods, 3rd ed. New York: Oxford University Press.

85. Hooper, D., Coughlan, J., \& Mullen, M. (2008). Structural Equation Modelling: Guidelines for Determining Model Fit. Journal of Business Research, 6(1), pp.53-60.

86. Henseler, J., C. M. Ringle, and M. Sarstedt (2015). A New Criterion for Assessing Discriminant Validity in Variance-based Structural Equation Modeling, Journal of the Academy of Marketing Science, 43(1), pp.115-135

87. Hair, J. F., M. Sarstedt, C. M. Ringle, and J. A. Mena (2012). An Assessment of the Use of Partial Least Squares Structural Equation Modeling in Marketing Research, Journal of the Academy of Marketing Science, 40(3), pp.414-433.

88. Gefen, D. and D. Straub, (2005). "Practical Guide to Factorial Validity Using PLS-Graph: Tutorial and Annotated Example," Communications of the Association for Information Systems, Vol. 16:pp.91-109

89. Hair, J. F., Ringle, C. M., \& Sarstedt, M. (2011). PLS-SEM: Indeed a silver bullet. Journal of Marketing theory and Practice, 19(2), pp.139-152

90. Henseler, J., C. M. Ringle, and M. Sarstedt (2015). A New Criterion for Assessing Discriminant Validity in Variance-based Structural Equation Modeling, Journal of the Academy of Marketing Science, 43 (1), pp.115-135

\section{AUTHORS PROFILE}

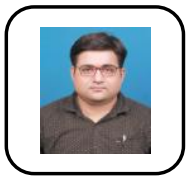

Dr. Pushkar Dubey is a Gold Medalist in Master of Business Administration from Sambalpur University having specialization in Marketing and Human Resource Management. His doctoral work includes the area of Human Resource Development and obtained his Ph.D degree from Dr. C. V. Raman University, Bilaspur. He has also cleared the UCG-National eligibility test in Management. Presently working as an Assistant Professor \& Head in Department of Management, Pandit Sundarlal Sharma (Open) University Chhattisgarh Bilaspur. Prior to his present post held he worked as Assistant Professor at Department of Management, Padmashree Krutartha Acharya College of Engineering (PKACE), Bargarh, Odisha, He has over 11 years of teaching experience. He is accredited with over 40 research papers in journals of National and International repute and has presented many papers in National and International Conferences and Seminars. He is also undergoing two Research Projects including one funded from IMPRESS - ICSSR, New Delhi. His key area of interest includes Human Resource Management, Organisational Behaviour, Entrepreneurship Development, Consumer Behaviour, Advertising and Marketing Research and has a firm hold in handling the Statistical packages including Smart PLS, SPSS and AMOS.

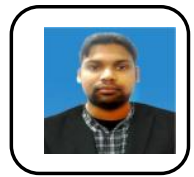

Mr.Satish Kumar Sahu is a Ph.D. scholar in the Department of Management from Pandit Sunderla Sharma (Open) University Chhattisgarh, Bilaspur, He has obtained and MBA (Marketing and Human Resource Management) and M.Phil (Management) from C.V. Raman University, Bilaspur, Chhattisgarh. His area of research includes Hospital Service Quality, Customer Loyalty, Hospital Administration and Management. 